\title{
Roberto Carlos como mediador cultural
}

\author{
Música jovem, tv e rádio
}

Marcelo Garson *

https://orcid.org/0000-0001-8767-1875

A década de 1960 é o momento em que a televisão toma as rédeas da música popular brasileira, reestruturando suas hierarquias de poder sob a égide de uma gramática audiovisual. Poucos elementos ilustram tão bem esse processo quanto o fenômeno de música jovem que se consolidou ao redor do musical Jovem Guarda, que estreia em agosto de 1965 na Tv Record, sob o comando de Roberto Carlos, Wanderléa e Erasmo Carlos, jovens das classes populares talhados pelo samba-canção, pop italiano, rock balada norte-americano e, fundamentalmente, pela sonoridade e visual dos Beatles.

A banda inglesa - que, a partir de 1964, conquista fama internacional - serviu de modelo para a construção da música jovem no Brasil, nicho que movimentou o mercado de discos, filmes, revistas, jornais e até artigos de consumo, como calças, botas, bonecos e lancheiras. Se, de maneira muito sintética, a Jovem Guarda se apresenta como uma beatlemania made in Brazil, é necessário termos muita cautela para não enxergar o fenômeno nacional como um mero "reflexo" de seu similar estrangeiro. É preciso dar conta das estruturas de produção, circulação e consumo de nosso cenário musical. A singularidade da Jovem Guarda está essencialmente ligada às convenções herdadas do rádio, instituição que, até os anos 1950, funcionava como epicentro da música popular brasileira.

* Universidade Federal do Paraná, Paraná, Brasil. 
Ainda que a TV, na década seguinte, tenha tomado o espaço do rádio como plataforma estruturante do cenário musical, a gramática radiofônica persistiu nas formas de cantar, divulgar as canções e interpelar o público televisivo - um público que, àquela época, não se repartia em nichos de consumo geracionais. Grandes modificações vieram com o sucesso inesperado da música jovem - via Bill Haley, Elvis Presley e, posteriormente, Beatles -, que obrigou as gravadoras a reavaliarem as estratégias de conquista de público no Brasil. A nova safra de artistas deixava cada vez mais claro que o mercado de música não se resumia ao material sonoro. As canções eram mais um elemento de um enorme comércio de narrativas de vida, que se desdobravam em diversos suportes com forte conteúdo imagético: filmes, reportagens, ensaios fotográficos etc.

A construção dessa gramática televisual, impregnada de resquícios do rádio, esteve ligada, pois, à emergência de um mercado jovem, processo que teve em Roberto Carlos um de seus principais personagens. Assim, ao analisar a trajetória do cantor entre 1956 e 1969 - do início de sua carreira profissional até o fim da Jovem Guarda -, buscaremos compreender como Roberto Carlos, a partir de estratégias herdadas do rádio e adaptadas para o novo meio, viabilizou-se enquanto ídolo televisivo, firmando-se tanto como celebridade jovem, quanto cantor das multidões. Logo, o objetivo deste artigo é perceber como Roberto atuou como um mediador cultural entre o rádio e a televisão e entre o mercado jovem e o massivo.

Apoiados em registros de época - reportagens, canções, capas de disco, filmes, livros -, cruzados com biografias do cantor e de demais agentes, buscaremos compreender os constrangimentos e constrições que explicam sua atuação em dois processos distintos, mas entrelaçados: a passagem da música popular do rádio para a TV e a construção do segmento de música jovem. A análise dos dados deixa claro que nem o mercado televisivo, nem o jovem dispunham ainda de uma gramática estabelecida. Tateando em busca de procedimentos de sedução por meio da imagem, Roberto participou ativamente, assim, do estabelecimento desses códigos.

O texto inicia esclarecendo as noções de trajetória e mediação cultural; elucida, em seguida, algumas convenções do universo radiofônico que constituirão o aprendizado de Roberto Carlos em seu relacionamento com as massas, o que, na sequência, nos permite compreender a trajetória do cantor em seu duplo movimento de conquista do segmento da música jovem e da audiência massiva.

\section{Mediação e trajetória}

Na sociologia, o conceito de mediação faz-se presente desde muito cedo. Em Marx (1983, pp. 159-170), por exemplo, trata-se de identificar o mecanismo que conecta 
base e superestrutura funcionando como regulador da vida social. Assim, o trabalho aparece como mediador fundamental, pois é a partir dele que o homem se apropria da natureza e imprime a ela sua marca propriamente humana. Mediante o trabalho o ser humano se torna ser social. No entanto, na sociedade capitalista o trabalho converte-se em mercadoria, o que faz do capital um mediador fundamental de trocas.

O termo reaparece na sociologia da cultura de Williams (1979) para discutir a relação entre arte e sociedade: interessa indagar como formas artísticas medeiam formas sociais. Para além de discussões basilares como essas, o termo é aplicado para dar nome a profissionais específicos que, no mercado de bens culturais, fazem as pontes entre os universos da produção, circulação e consumo de bens culturais, como editores, livreiros, críticos, jornalistas, produtores culturais, radialistas etc. (Janssen e Verboord, 2015; Montoya, 2008; Pequignot, 2007).

Com o intuito de pensar uma antropologia das sociedades complexas, Gilberto Velho considera os mediadores culturais como agentes que estabelecem pontes, trânsitos e elos, funcionando como intérpretes entre universos distintos (Velho e Kuschnir, 2001). Nas sociedades complexas, em que a diferenciação de papéis, regras de status e sistemas simbólicos é uma realidade incontornável, eles agem como intermediários, articulando as conexões necessárias ao funcionamento do sistema. A habilidade do mediador, portanto, está em lidar com códigos culturais nem sempre harmônicos. Disso resulta um processo de interação e comunicação tenso, repleto de conflitos e alianças.

A noção fez-se presente no trabalho de Karina Kuschnir (2000), em que políticos são tomados como mediadores, pois traduzem e conformam os desejos e vontades de diversos grupos sociais. Já na tese de Igor Sacramento (2012), o mesmo papel é atribuído a Dias Gomes, dramaturgo que conciliou sua posição de membro do partido comunista com sua atuação em veículos da grande mídia. No campo da música, Letícia Vianna (1999) investiga como Luiz Gonzaga e Bezerra da Silva se tornaram porta-vozes, respectivamente, do Nordeste e do morro na grande mídia. De forma semelhante, Simone Sá (2002) investiga como Carmen Miranda, a meio caminho entre o Brasil e os Estados Unidos, negociou uma imagem singular, no contexto da Política da Boa Vizinhança, que ultrapassa o clichê de baiana tropical que lhe é comumente atribuído. Por fim, podemos citar a coletânea de Ângela de Castro Gomes e Patricia Hansen (2016) que analisa a trajetória de intelectuais mediadores - livreiros, editores, escritores - na interface entre política e cultura (Castro Gomes e Hansen, 2016).

Em certa medida, todos os indivíduos, atravessados por relações sociais distintas e conflituosas, acabam, em algum grau, exercendo a atividade de mediadores. Isso, no entanto, não esvazia a importância da noção, mas nos faz indagar acerca de sua natureza. De que maneira a mediação ocorre? Que forças sociais se cruzam? Quais 
são as tensões observadas? São essas as questões que nos fazem estudar os mediadores.

A noção de mediação se soma à de trajetória. $\mathrm{O}$ estudo das trajetórias e projetos de vida é uma maneira de lidar com a importância das escolhas individuais, mas também de evidenciar a existência de elementos conjunturais e estruturais, nem sempre conhecidos, que pensam sobre a ação do sujeito (Velho e Kuschnir, 2001).

Ao reconstituir a vida de um personagem é necessário escapar ao que Bourdieu (1996) chama de ilusão biográfica: a crença na possibilidade de reconstituir um conjunto coerente, ordenado e linear de acontecimentos que se orientam para um fim e um propósito predeterminado. Para tanto, é necessário tomar tanto o agente quanto o espaço social em que ele se desloca como um "devir estando sujeito a sucessivas transformações" (p. 189). Isso implica reconstruir sua dimensão estrutural, ou seja, o conjunto de relações objetivas que organizam o campo e que distribuem os agentes e os grupos sociais segundo relações de proximidade ou distância. Dessa maneira conseguimos compreender o espaço dos possíveis, ou seja, as possibilidades de tomada de posição em meio aos constrangimentos que se colocam - constrangimentos esses que, em maior ou menor grau, podem ser modificados pela ação dos sujeitos.

Estudar a trajetória artística de Roberto Carlos é compreender como a adesão à música jovem lhe apareceu como contingência: uma estratégia para a profissionalização e inserção mercadológica. Não se trata, portanto, de uma teleologia, mas de perceber como um cenário musical em transformação respondia a tendências de mercado que se globalizavam. O surgimento da música jovem se deu no mesmo momento em que as convenções da música popular são reconfiguradas sob a égide da televisão. Essa reconfiguração, no entanto, dava-se a partir de bases previamente dadas por uma gramática radiofônica que se plasmava não só em estruturas sociais, mas também em estruturas mentais, ou seja, em uma racionalidade específica que se traduz em modos de pensar, agir e classificar a realidade, afinada com determinantes objetivos dos quais os agentes nem sempre têm consciência. Em um cenário como a música massiva, em que a dimensão heterônoma é central, é necessário reconhecer o jogo plástico em que a autonomia criativa e as forças mercadológicas se entrelaçam. Deste modo, é possível perceber um certo grau de indeterminação no trabalho de Roberto Carlos, trabalho esse que constitui, antes, um processo em construção que um produto dado de antemão.

Respeitando os limites estabelecidos por relações de força e jogos de poder próprios à indústria da música, tentaremos articular as hesitações, incertezas e escolhas que incidiram na carreira de Roberto Carlos e dependeram não só do artista, mas dos agentes, grupos e instituições que organizavam o universo da música popular. Uma atenção especial será dada a suas representações midiáticas, síntese do campo de forças que o fabricou enquanto ídolo popular. 
Sua biografia (Araújo, 2006) mostra como seu objetivo era se tornar um ídolo das massas ao estilo Cauby Peixoto - desejo, que, entretanto, foi se adequando às possibilidades apresentadas. Cabe agora compreender qual era o campo de possibilidades aberto aos aspirantes a ídolo.

\section{A idolatria no rádio}

Até a década de 1950, os programas de auditório representavam um dos pilares de sustentação de todo o sistema de estrelato radiofônico. Passar pelo crivo da audiência era condição indispensável para o sucesso. Cantores consagrados, calouros, comediantes, humoristas e até mágicos eram as atrações desses shows de variedades que duravam até cinco horas. A qualidade do espetáculo era proporcional à catarse da plateia, que cantava, ria, aplaudia e vaiava. Grande parte do entusiasmo se baseava na rivalidade forjada entre cantoras, como Emilinha Borba e Marlene, que eram transformadas em celebridades em meio a aplausos, vaias e até agressões físicas trocadas pelas integrantes de seus fã-clubes.

Com entrada livre ou ingresso bastante acessível, os programas de auditório cativavam as camadas baixas e suburbanas que se organizavam em caravanas, levavam cestas de comida e até dormiam na fila para garantir o lugar. Apresentadores como Cesar de Alencar chegavam a fazer referências explícitas aos bairros pobres do subúrbio e aos estados de origem da massa imigrante que lá costumava se abrigar: "Paraibanos, esse programa é pra vocês" (McCam, 2006, p. 190). O encontro face a face das audiências era mediado por publicações como a Revista do Rádio que, ao divulgar atrações, concursos e, principalmente, revelar as intimidades dos astros, atuavam como meios de incendiar ainda mais os auditórios. Por meio de colunas de fofocas e de uma movimentada seção de cartas de leitores, alimentavam ainda mais a rivalidade e a participação do público. Funcionavam, assim, como locais de construção, conhecimento e reconhecimento e distinção das audiências, como já mostramos em outra ocasião (Garson, 2017).

Passar pelo crivo dos auditórios era o rito de passagem obrigatório aos aspirantes a ídolo popular. Nesse rádio feito ao vivo, Roberto Carlos aprendeu estratégias de cativar o público através de canções, performance de palco ou aparições em revistas, jornais, e, posteriormente, televisão e cinema. E quanto ao repertório, foi a música romântica - boleros, guarânias e sambas-canção, ritmos de grande sucesso desde a década de 1930 - que formou a base de sua obra.

Nos anos 1960, com o barateamento dos receptores, a televisão expande o seu público e passa a optar por uma programação mais popular, abandonando o experimentalismo e a liberdade da década anterior. A música e as novelas ganham força no 
novo meio, que abocanhou verbas publicitárias do rádio e pôs os grandes cantores sob contrato, levando ao declínio os tradicionais shows de auditório das rádios. Mas se os programas se esvaziaram, o auditório, enquanto polo de consagração cultural e matriz de práticas sociais, continuava vivo. Foi a habilidade em transplantá-lo para a gramática televisual nascente que respondeu por grande parte da consagração de Roberto Carlos. É esse processo que estudaremos a partir de agora.

\section{João Gilberto dos Pobres}

Nascido em 1941, em Cachoeiro do Itapemirim, interior do Espírito Santo, filho da costureira Laura Moreira Braga e do relojoeiro Bernardino Braga, Roberto Carlos Braga teve a infância e a adolescência marcadas pelo contato com o rádio. Tangos, guarânias, valsas, sambas-canções e boleros forjaram seu repertório e estilo romântico de interpretação, cultivados até hoje. Quando criança, apresentou-se em shows e caravanas de calouros mirins com um repertório adulto inspirado nos grandes cartazes de então.

Chegando ao Rio de Janeiro em 1956, instalou-se no bairro suburbano de Lins de Vasconcelos. Passava os dias nas rádios procurando oportunidades para se apresentar, mas sua experiência pregressa como calouro, além da habilidade com o violão e piano, não valiam muito no cenário musical mais competitivo do país. Paralelamente, garantiu o diploma escolar estudando à noite. Na mesma época, integrou-se a um grupo de jovens que se reunia na Tijuca, bairro vizinho a Lins. Ao lado de futuros ídolos da música, como Jorge Ben, Wilson Simonal e Tim Maia, Roberto participou de serestas e compartilhou o gosto por cinema e quadrinhos norte-americanos.

Com Tim Maia, fundou o quarteto vocal Os Sputniks, cujo repertório, em inglês, era retirado de rocks ouvidos no rádio, apesar de seus integrantes desconhecerem o idioma. Apresentaram-se em igrejas e clubes suburbanos até conhecerem Carlos Imperial, que fazia parte do show de variedade Meio Dia, como produtor de um quadro intitulado "Clube do Rock". Nele, Roberto e Tim encarnavam, respectivamente, o Elvis Presley e o Little Richard brasileiros, dançando e dublando hits estrangeiros até 1959, quando o show foi cancelado.

Nesse ano, Roberto enxergou na emergente Bossa Nova a possibilidade de profissionalização. Com um repertório de bossas e sambas, atuava como crooner da boate Plaza em Copacabana. Notando a semelhança com o canto de João Gilberto, Imperial decide lançá-lo como o “príncipe da Bossa Nova” (Monteiro, 2008, p. 12). Seu primeiro compacto, que reproduz abertamente os trejeitos vocais de João Gilberto, não vendeu bem, nem conseguiu estabelecê-lo nos círculos de bossa. Quando todos se esforçavam para cantar como Gilberto, o capixaba acreditava estar apto a se tornar um cantor de bossas profissional, pois dominava o repertório, e sua voz miúda 
e suave se adaptava muito bem à performance vocal própria ao gênero. Aprenderia, da pior maneira, que estava errado.

Apelidado de “João Gilberto dos Pobres” (Araújo, 2006, p. 112), sua interpretação era encarada como cópia - destituída dos signos extramusicais de legitimação. Os círculos de bossa eram formados por jovens universitários de classe média, moradores da parte nobre da cidade, a zona sul. A realidade de Roberto Carlos era bastante diferente: interiorano e agora suburbano, com grande dificuldade completara o ensino secundário e ainda trabalhava como músico para sobreviver. Para os estetas da bossa nova, nada mais vulgar do que um calouro de auditório, que buscava converter uma proposta aparentemente desinteressada de vanguarda em ganha-pão e, pior, em atalho para o sucesso massivo. Quanto mais a Bossa Nova se difundia, maiores eram as barreiras utilizadas para manter os arrivistas longe das reuniões de apartamento e do circuito de shows universitários. Assim, destituído de capital cultural e social, a técnica vocal do capixaba era desprovida de rentabilidade simbólica. Isso mostra de que maneira a classe social organizava as chances de acesso a determinadas posições, evidenciando seu caráter estruturante no mercado musical.

Isso, no entanto, não impediu Roberto e Imperial de continuarem apostando no gênero, como mostra o segundo compacto do cantor, que possui um samba orquestrado ("Canção de amor nenhum") e uma bossa ("Brotinho sem juízo"). Na segunda composição, é interessante perceber como o diálogo com uma cultura juvenil emergente, que caracterizaria o universo simbólico da Jovem Guarda, já estava ali presente. A letra possuía um claro apelo moralista ${ }^{1}$, recobrindo o mesmo universo semântico e moral dos rocks "bem comportados" da dupla de compositores Paul Anka e Neil Sedaka, que já haviam influenciado Celly Campello, a "rainha do rock brasileiro" em fins dos anos 1950.

\section{Suburbanos norte-americanos}

Em 1961, Roberto lançou seu primeiro LP, Louco por você (Carlos, 1961), que se inspirava não só na bossa nova, mas nos rocks de Sergio Murilo - primeiro ídolo brasileiro do gênero -, no bolero de Anísio Silva e no samba de Miltinho (Araújo, 2006). Louco por você incluía, em ritmo de bossa, a representativa "Ser bem”. A canção fazia menção ao jornalista [Jean] Pouchard e aos personagens - os playboys Jorginho [Guinle] e Baby [Pignatary] -, ambientes - as boates Copa e Sacha's e o clube de equitação Hípica - e eventos - o concurso de beleza Miss Elegante Bangu - que

1. "Brotinho toma juízo/ Ouve o meu conselho/ Abotoa esse decote/ Vêse cobre esse joelho [...]" (Carlos, 1961). 
povoam sua coluna social, evidenciando como o imaginário midiático de glamour e consumo, recheados de signos norte-americanos, povoava os desejos de ascensão de jovens como Roberto.

O lançamento do disco acompanhava a construção da imagem do cantor pelas mãos de Carlos Imperial, que então estava à frente de Os Brotos Comandam, programa de TV baseado em rock and roll, chá-chá-chá, twist e hully gully. Além da TV, Imperial também divulgava as novidades da música jovem na Revista do Rádio.

Com o lançamento do primeiro LP, é possível ver o nome da faixa título "Louco por você" nas paradas de sucesso da Revista do Rádio, acompanhado por uma nota na coluna de fofocas "Mexericos da Candinha", que dizia: "Romance em evidência de brotinhos. A nova cantora Rosemary e Roberto Carlos, cantor de Bossa Nova" (“Mexericos...", 1961). "Bossa nova” e "brotinho" são dois elementos importantes para compreender a posição de Roberto no mercado musical. O primeiro grupo já estava razoavelmente definido, enquanto o segundo apontava para um núcleo de artistas que ainda se desenhava.

A geração dos brotos seria explorada em outra matéria da mesma revista, a qual apontava que o então "Rei dos Brotos”, Cauby Peixoto, estava sendo ameaçado por nomes como Sergio Murilo, Agnaldo Rayol, Pery Ribeiro, Tony Campelo e Demetrius e ainda "Roberto Carlos que é uma coqueluche da juventude" (“Cauby...”, 1961, p. 15). A única semelhança entre todos esses cantores era a proximidade etária, já que os universos sonoros em que habitavam eram diferentes. Sergio Murilo, Tony Campelo e Demetrius apostavam no rock; Agnaldo Rayol, na música romântica; e Pery Ribeiro, na bossa nova; Cauby, o clássico ídolo que veio do rádio com um repertório extremamente diversificado. Os três primeiros utilizavam a juventude como forma de se promoverem; os demais, não. Roberto Carlos estava entre a bossa nova e a música jovem em um típico cenário de indefinição. A contracapa de Louco por Você o caracterizava como alguém que "encontrará o seu lugar na linha de frente dos jovens e talentosos artistas da nova geração”.

Na mesma Revista do Rádio, Imperial mantinha uma seção chamada "O Mundo é dos Brotos". Nela, um quadro com a parada de sucesso de cinco países ocupava um terço de toda a página, seguido de pequenos textos informativos. Falava de rock, mas também dos cantores italianos que estouravam no festival de San Remo; "os maiores”, “os cobras", “os preferidos”, “os sucessos”, “os líderes de audiência” eram o que interessava noticiar. Isso deixava claro que, para Imperial e os jovens que gravitavam ao seu redor, como Roberto, tornar-se um ídolo era mais importante que tornar-se um ídolo de música jovem, pois poucos acreditavam na longevidade desse nicho de mercado recém-formado. Isso explica por que Roberto nunca descurou da canção romântica, ainda que se tenha tornado o maior astro jovem do período. 
A partir de 1962, Roberto assume o posto de ídolo juvenil da gravadora CBS, substituindo Sergio Murilo, que pouco antes ocupara o posto de "Rei da Juventude" ao lado de Celly Campello. Sua imagem abandonava o universo adulto da bossa para se ancorar nas referências à cultura juvenil norte-americana dos anos 1950, que nos chegava através do rock and rolle de filmes como Juventude Transviada e Ao Balanço das Horas. Assim, tornavam-se corriqueiras declarações como a seguinte: "três são as coisas que Roberto mais aprecia na vida: cantar e ter um carro de corrida, além dos brotos, naturalmente" ("Paixões...", 1962, p. 15).

A origem popular e interiorana constituiu o ponto de partida para a narrativa linear que construía Roberto como o sujeito que veio "de baixo” e triunfou graças ao esforço individual. Ele era "o rapaz do Espírito Santo, que veio vencer no Rio, em rádio, em discos e TV" (“O mundo...", 1962, p. 29). Sua rotina se resumia a "fãs ao telefone e uma trabalheira: viagens para cá e para lá. Roberto Carlos tem que se alimentar forte para aguentar a luta. Mas, quem disse que ele não gosta dessa vida de 'estivador'?" ("Paixões...", 1962, p. 16). Ele se afirmava como um modelo, "um professor em caitituagem e seu maior valor reside principalmente na disposição para o trabalho. Acorda às $7 \mathrm{~h}$ da manhã, diariamente, para fazer tocar os seus discos. Que ele sirva de exemplo aos novos valores que surgem e, antes de serem artistas, já estão acomodados, não demonstrando interesse pela carreira" "“O mundo...”, 1962, p. 29).

"Estivador" e "professor de caitituagem" eram maneiras de definir e legitimar o trabalho análogo ao braçal que caracterizava o universo da música popular e seus artistas majoritariamente oriundos das baixas camadas sociais. Caitituar era o mesmo que frequentar insistentemente os programas de rádio a fim de divulgar suas canções. Até então, o capixaba já havia trabalhado como crooner e se apresentado em igrejas, circos e espetáculos populares. Como datilógrafo, complementava as inconstantes remunerações. Assim, a representação de Roberto, embora voltada para a construção da imagem de um ídolo jovem - distinta, portanto, dos astros já consagrados -, construía-se de forma muito semelhante a tantas trajetórias de sucesso estampadas na Revista do Rádio, como a de Ângela Maria, que havia sido operária, e de Orlando Silva, office-boy.

A narrativa típica enfatizava as origens humildes, o esforço individual e o brilho da fama que, contudo, não o deixariam esquecer seu apreço à família e ao público que o consagraram. Ao ser eleito "Favorito da nova geração", em uma cerimônia que ainda celebrava os vinte anos de carreira da grande estrela dos auditórios Emilinha, ficava clara a aderência do novo cantor ao universo simbólico do rádio, com seus reis, rainhas e concursos.

Roberto assumia, assim, o papel de mediador ao negociar o cruzamento da nova simbologia juvenil com o universo radiofônico tradicional, massivo, popular e 
suburbano, que progressivamente era incorporado pela TV. Isso explica uma simbologia baseada na exaltação das origens humildes e disposição para o trabalho, com o hedonismo das festas, carros e diversão, presentes nos filmes, canções e quadrinhos juvenis norte-americanos.

\section{A construção de um ídolo jovem}

Os anos de 1963 e 1964 foram fundamentais para Roberto se projetar como ídolo jovem. Com Splish splash ${ }^{2}$ já se definem alguns signos característicos das composições da Jovem Guarda: humor, ausência de acompanhamento orquestral e alusões a um estilo de vida jovem e hedonista. Na canção - que narra, com ironia, a história de um beijo roubado e devolvido com um safanão -, a orquestra, presente nas composições anteriores, é substituída pela banda Renato e seus Blue Caps. O humor se faz presente na letra, que narra o infeliz destino prosaico do eu lírico, mas também na inserção de risadas, que ridicularizam a condenação a práticas "tipicamente" juvenis, como, no caso, o namoro no cinema. A canção está no mesmo LP de "Parei na contramão", composição que mistura a temática dos carros e da paquera juvenil, ao narrar a história de um motorista que fura o sinal em busca do "broto displicente" e acaba tendo a carteira de habilitação apreendida.

Essa leva de canções evocava o universo da juventude transviada, a qual, para além do filme homônimo, aludia a playboys motorizados que apavoravam Copacabana, tópico extremamente debatido na imprensa dos anos 1950. O automóvel, a velocidade e a conquista amorosa construíam a juventude como esfera de liberdade e prazer. Ao mesmo tempo que se utilizavam da noção de delinquência para conectar-se com o imaginário midiático de então, as composições faziam uso do deboche e ironia, como meio de eliminar qualquer vestígio de desvio. Além disso, as faixas de levada mais acelerada e narrativa dinâmica conviviam com outras cujo tom confessional adaptava a vasta tradição romântica da música popular radiofônica ao universo juvenil das festas, brotos e namoros adolescentes.

A partir do segundo LP, a imagem do cantor está cada vez mais vinculada à sua mãe. Apontava-se, assim, tanto na direção do fã de música jovem quanto da família reunida ao redor da TV e do rádio. A mãe se tornava o elo entre vida pública - da rua e do rádio - e vida privada - ligada à intimidade do lar.

2. "Splish splash!/ Fez o beijo que eu dei/ Nela dentro do cinema/ Todo mundo olhou me condenando/ Aha! Aha!/ Só porque eu estava amando/ [...] Splish splash/ Fez o tapa que eu levei/ Dela dentro do cinema/ Todo mundo olhou me condenando/ Só porque eu estava apanhando" (Carlos, 1963). 
Enquanto [acordo] mamãe pessoalmente cuida do meu café com leite, pão, frutas, geleia de morango. [...] Se não tiver programa entre 19 e 21 horas, [...] sou pontual [...] para jantar com meus pais [...]. Gosto das macarronadas que [mamãe] faz, dos suculentos bifes com [...] fritas (“Como vive..., 1964, p. 14).

O caráter nitidamente trivial de reportagens como essa era uma forma de fabricar uma sensação de intimidade mediada; uma "performance pública da vida privada" (McDonnel, 2012, p. 35). Assim, Roberto ultrapassa o status de ídolo jovem, mostrando-se uma figura "do povo", "igual a todos nós", que, mesmo cercado de garotas, não perdia a macarronada da "mamãe". Com um pé na plateia e outro além dela, Roberto construía-se mediante uma dialética de identificação e distinção: "É importante dizer que o sucesso não o modificou. Continuou sendo o bom rapaz, simples e alegre, tem sempre palavras de gratidão para aqueles que o ajudaram a subir" (“TodA A...”, 1965, p. 12).

A estratégia, no entanto, não era inédita. Desde a década de 1940, a Revista do Rádio mostrava o lado mundano da vida dos artistas, contrastando o glamour do estrelato com atividades cotidianas, tais como cozinhar e passear com o cachorro. O que muda é a maneira como essa estratégia é adaptada à construção de um ídolo jovem: "detesto o paletó e gravata [...] mesmo quando viajo não deixo de estar de camisa esporte e calças blue jeans [...]" (Idem).

Depois de "Splish splash" e "Parei na contramão", "É proibido fumar" firma $^{2}$ ainda mais o nome de Roberto no mercado jovem. Abrindo o seu terceiro LP, a faixa continha a ironia e o deboche característicos das duas outras composições, investindo, ainda, na figura do conquistador livre de amarras que, na sua rebeldia inofensiva, "[Seguia] incendiando, bem contente e feliz/ Nunca respeitando o aviso que diz/ Que é proibido fumar!”. O tema dos carros e da velocidade voltava com "Calhambeque", uma ode ao automóvel, o qual, na década de 1960, era tanto símbolo de prosperidade da nação quanto índice de status do indivíduo - o "meu" carro, símbolo do "meu” sucesso (Figueiredo, 1998). Na capa do disco, há uma foto estática do cantor de braços cruzados, semblante sério e trajando camisa vermelha, cor que remetia, ao mesmo tempo, ao fogo, de "É proibido fumar", mas também à juventude transviada, rotulada na imprensa, desde a década anterior, como grupo que "dança 'rock and roll', veste camisa vermelha, masca chiclete e usa 'blue jean'(sic)” (Silva, 1958, p. 33). Na contracapa do disco, Roberto aparecia em uma imagem em preto e branco, trajando suéter, calça e sapatos escuros, com os braços

3. "Eu pego uma garota e canto uma canção/ E nela dou um beijo com empolgação, rá!/ Do beijo sai faísca e a turma toda grita/ Que o fogo pode pegar, ah!” (Carlos, 1963). 


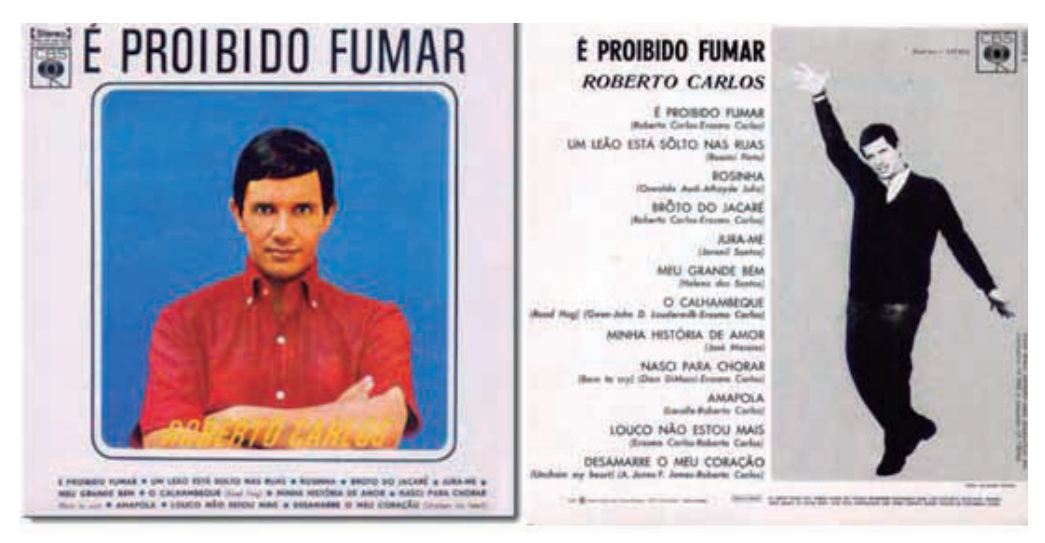

É proibido fumar.

Fonte: https://www.discogs.com/pt_BR/artist/286945-Roberto-Carlos, consultado em $18 / 1 / 2020$.
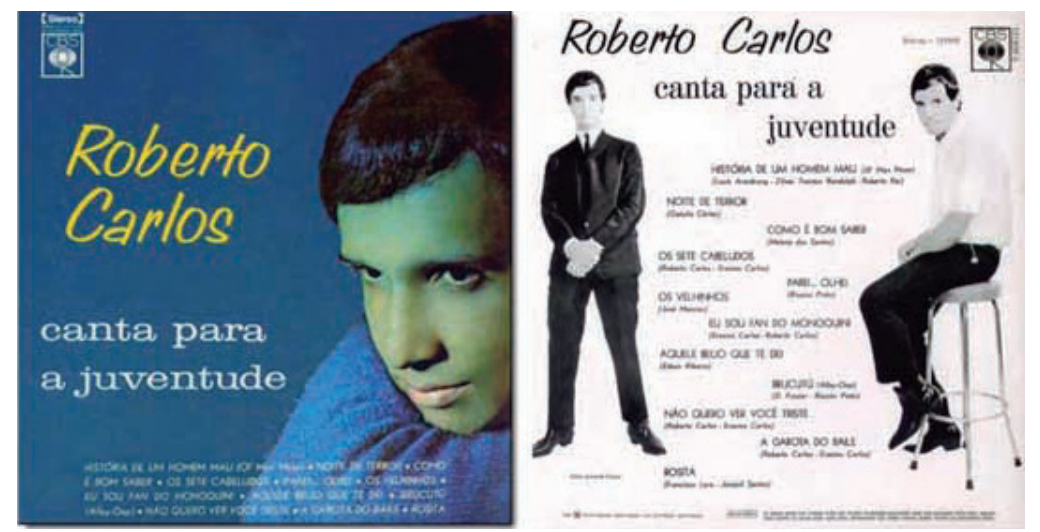

Roberto Carlos canta para a juventude.

Fonte: https://www.discogs.com/pt_BR/artist/286945-Roberto-Carlos, consultado em $18 / 1 / 2020$. 
abertos e a mão direita espalmada, apontando para cima e esboçando um sorriso discreto, como a indicar um gesto de liberdade. Mais uma vez, o jogo de oposições era mobilizado de forma irônica.

Seu próximo disco, Roberto Carlos canta para a juventude, investia no universo propriamente juvenil dos filmes, quadrinhos e séries de faroeste, ao narrar o duelo de cowboys ("História de um homem mau"), o encontro com Frankenstein ("Noite de terror") e a briga entre turmas de rua ("Os sete cabeludos"). O acompanhamento instrumental ganhava um toque de modernidade e cosmopolitismo ao contar com um órgão Hammond, comum em filmes de ficção científica como $O$ dia em que a Terra parou. Nas faixas românticas, o instrumento promovia a releitura moderna do tradicional repertório romântico e lacrimoso; e nas de apelo mais jovem, criava efeitos sonoros que, somados a gritos, sirenes e buzinas, produziam uma narrativa dinâmica e fragmentada que remetia a filmes e quadrinhos. A contracapa desse disco é composta por duas imagens reveladoras: de um lado, Roberto, sentado em um banquinho, veste uma camisa branca e calça preta; de outro, metido em um terninho de quatro botões, reproduz a popular indumentária dos Beatles. Enquanto o visual minimalista e o banquinho apontavam para a bossa nova, um passado já superado, a referência à banda inglesa indicava qual seria o eixo condutor da música jovem daí em diante.

\section{Entre o nicho e a massa}

A estreia do programa Jovem Guarda na TV Record, em agosto de 1965, cria um acontecimento até então sem paralelo na história da música popular brasileira. Rotulado de "Rei do ié-ié" (Oliveira, 1966, p. 29), Roberto se construía como um tipo especial de monarca que parecia ter sido alçado ao trono pela audiência midiática que cativara. Então, para além de uma questão hereditária, já que ele parecia localizar-se na linha sucessória dos astros do rádio, o trono lhe era de direito por uma questão de merecimento. De acordo com a narrativa, registrada sobretudo na mídia impressa, para além de colher os frutos "naturais" do "trabalho duro", possuía um carisma que lhe era inerente. Construído socialmente, o carisma do cantor é um efeito do diálogo com diversos signos midiáticos capturados do rádio, imprensa e cinema, adaptados à lógica televisiva. O playboy, personagem que se popularizara no colunismo social da década de 1950, expresso na já citada canção "Ser bem" ${ }^{4}$, havia criado o padrão

4. “Ser bem/É no Copa debutar/ É sair todo domingo/ Na revista do Pouchard/ Ser bem/É andar de Cadillac/ É dizer que está 'in love'/ Mesmo que seja de araque/ Toda garotinha bonitinha tem mania/ De ser elegante da Bangu/ Quer ver o seu nome na coluna todo dia/ Pertinho do Jorginho, ao lado do Didu/ Ser bem é na Hípica jantar / É no Jóquei desfilar e de noite, no Sacha’s/ Com Baby, juntinho dançar/ Mamãe, eu também quero ser bem" (Carlos, 1961). 
narrativo apropriado por Roberto. Ele ostentava desmesuradamente suas riquezas, revelando a lógica de uma cultura de consumo em que o sucesso do indivíduo era pontuado pela aquisição de bens materiais.

A imprensa falava muito de sua coleção de carros importados e de seu apartamento forrado de veludo azul, decorado com obras de arte abstratas e móveis de jacarandá. Para abri-lo, uma chave de ouro maciço com seu nome gravado ("Periscópio”, 1966, p. 7). O ouro, a prata, o veludo, o jacarandá, as obras de arte e o carro fundiam símbolos de poder de um monarca tradicional e de um burguês industrial, revestido por certo exagero arrivista: o rei encontrava-se com o playboy e o suburbano endinheirado em um conto de fadas afinado à sociedade do consumo.

A performance do músico se adaptava à nova gramática da música, que, ao ser dragada pela TV, tornava-se cada vez mais visual. Na década de 1960, além da Revista do Rádio, novas publicações se ocuparam da vida íntima dos astros, como a Intervalo e a Contigo. Especializada no universo televisivo, Intervalo documentou intensamente o cotidiano da Jovem Guarda e da nascente MPB. Já a Contigo, “a revista jovem para os jovens brasileiros", investia na segmentação geracional através de longas matérias com os ídolos emergentes e ainda dedicava cuidado especial às fotografias em cores, elemento importante desse novo regime imagético.

Para os cantores da Jovem Guarda, o corpo era marca distintiva fundamental, sendo explorado em blusas abertas de tons berrantes e estampas chamativas, minissaias, calças boca de sino, cabeleiras beatle, anéis, botas e pulseiras que brilhavam nas fotografias de revista ou telas de TV. Nos palcos do Jovem Guarda, gírias como "é uma brasa, mora”, já impregnadas na linguagem popular, combinavam-se aos meneios corporais de Roberto Carlos, tornando-se marcas registradas. A esses elementos somava-se uma sonoridade eletrificada em um palco decorado com imagens de carros e retratos do cantor. Assistir a ele em ação era muito diferente de escutar suas músicas.

Antes de tudo, é um frenesi. Ouvi-lo já é agradável, mas muito melhor é vê-lo num auditório, exprimindo com gestos arrebatados a sua força juvenil, o seu amor à vida e a sua alegria. Esse rapaz, que fará 22 anos em abril, tem um rosto meio de anjo - o qual naturalmente vem ornado por uma bela cabeleira negra e sedosa. [...] Temos pois no palco um belo rapaz que canta e gesticula. Mas diante dele [...] milhares de mocinhas que gritam desesperadamente o seu nome (“Oh! Ele é um pão”), que desmaiam, que balbuciam declarações de amor. Há também rapazes [...] à procura [...] do magnetismo do cantor, do qual já adotaram os cabelos e o estilo exterior (Oliveira, 1966, p. 85).

Embalada pelo ritmo da canção e vibrando, a plateia do auditório está eletrizada. 
No fundo do palco, iluminado sem nuances, há desenhos de calhambeques. As lentes das câmaras são os olhos de milhares de pessoas [...] todas as atenções se derramam sobre um novo ídolo. Roberto Carlos, de calças apertadas e longos cabelos pretos [...], ele é o rei absoluto de nosso iê-iê-iê. [...] Como se explica o fenômeno Roberto Carlos? [...] a juventude explica tudo [...] - tanto o deus idolatrado quanto os crentes que o idolatram. Veja-se, [...] o sucesso dos Beatles, tudo neles é jovem, [...]: as roupas, o ritmo, o jeito de sorrir e, principalmente, as letras de suas composições. Nesse último item também está uma das chaves do êxito de Roberto Carlos (Soares, 1966, p. 29).

Quem assistiu ao programa no Teatro Record não tinha mais de vinte anos. A maioria era de meninos e meninas usando calça Lee e botinhas, que subiam e desciam no compasso do rock (“Roberto Carlos foge...”, 1965, pp. 14-15).

Assim, o êxito de Roberto dependia de como construía uma ideia de juventude pela via audiovisual. Mediante gestos, indumentária, cabelo, gírias, entonação de voz e repertório, ele fabricava não só a posição de ídolo, mas de ídolo jovem. Essa performance de autenticidade era feita sob medida para a audiência doméstica e televisiva, mas também para o público eletrizado que assistia a ele ao vivo, o que remetia a uma das mais tradicionais instâncias de consagração da música popular: o auditório das rádios. Veremos, no entanto, que sua posição de ídolo jovem era somente um degrau para atingir seu objetivo, tornar-se um ídolo das massas.

Se a existência de fã-clubes remontava às disputas de popularidade entre ídolos do rádio, a questão, agora, era como imprimir ao fenômeno um caráter jovem. Isso explica o esforço da mídia na caracterização detalhada do público. O frenesi juvenil era uma das temáticas preferidas nas matérias sobre os Beatles que, desde 1964, inundavam a imprensa brasileira. Não surpreende que os mesmos adjetivos fossem usados para a Jovem Guarda: "Roberto Carlos quase nu e todo arranhado fugiu num Volkswagen verde enquanto mais de trinta meninas - todas usando calças ou saias Lee e o competente cinturão de vaqueiro americano - ficaram gritando na porta do teatro Record e logo depois brigando e chorando em disputa do que restava da camisa vermelha do cantor" ("Roberto Carlos foge...", 1965, p. 14). A mídia, portanto, já tinha dado conta de rotular e publicizar o fenômeno da idolatria que irrompia nos anos 1960 como propriamente juvenil, mesmo antes de Roberto Carlos chegar aos palcos da Record. Mas a figura do cantor também evocava uma dimensão melancólica.

Jovem Guarda (Carlos, 1965a) é o nome do quinto LP de Roberto Carlos. Sua capa exibe quatro imagens do cantor com semblante introspectivo; barras verticais e coloridas contrastam com essa figura e dão movimento à composição. $\mathrm{O}$ ritmo 
dinâmico que caracterizava o programa Jovem Guarda está presente em faixas como "Lobo mau"s e "Não é papo pra mim"6. Enquanto essas duas canções resgatam novamente a figura do playboy conquistador, hedonista e "cafajeste", em "Mexericos da Candinha"7 o cantor remetia à seção homônima de fofocas da Revista do Rádio e às críticas que lá recebia, a fim de reiterar o caráter nada ameaçador de seu comportamento e visual. Merece atenção especial "Quero que vá tudo pro inferno" ", canção que conseguiu dialogar, ao mesmo tempo, com o público massivo e o segmento juvenil, fazendo de Roberto o maior vendedor de discos de 1966. Tratava-se de uma crônica sobre a solidão nas grandes cidades, que reitera o caráter implacável do sofrimento, apesar das promessas hedonistas do consumo. A afirmativa ganhava credibilidade na boca de Roberto, que, apesar da ascensão meteórica, ainda conservava um certo tom melancólico em sua imagem pública. A composição, assim, inseria o playboy endinheirado no universo lamurioso do bolero e samba-canção, dialogando com o vasto público que descendia do rádio. Esse apelo mostrava que Roberto buscava dialogar com diversas faixas da audiência, não se restringindo somente ao público jovem. Outras propostas vão na mesma direção.

Em maio de 1966, o cantor participou do concerto Jovem Guarda em Estilo Clássico, cuja proposta era fundir sucessos jovens com a música erudita, misturando intérpretes da Jovem Guarda, cantores líricos, banda e orquestra. Em abril de 1967, chegava às livrarias Roberto Carlos em prosa e verso, o primeiro de uma série de quatro livros que contêm poemas, crônicas e até um roteiro de teatro. No mesmo ano, o cantor interpreta "Maria, carnaval e cinzas", canção de temática engajada, no III Festival da Música Popular. Vitrine da MPB, o evento nutria rejeição enorme aos artistas da Jovem Guarda, o que não impediu Roberto de angariar o quinto lugar.

Ao mesmo tempo que lançava a linha de roupas Calhambeque, composta de calças, botas, cintos e demais itens para adolescentes, ele flertava com a música erudita, poesia e repertório engajado. Essas iniciativas não devem ser compreendidas como tentativas de se legitimar nessas esferas, mas, sim, como formas de oferecer às mais diversas audiências a possibilidade de consumir o ídolo em múltiplos formatos. Isso explica por que se apresentava em pavilhões, clubes, ginásios e estádios, para públicos

5. "Eu pego o meu carro e começo a rodar/ E tenho mil garotas/ me chamam lobo mau [...]/ eu sou o tal" (Carlos, 1965).

6. "Casamento enfim/ Não é papo pra mim" (Carlos, 1965).

7. "A Candinha vive a falar de mim em tudo/ Diz que eu sou louco, esquisito e cabeludo/ [...] Mas a Candinha agora já está falando até demais/ Porém ela no fundo sabe que eu sou bom rapaz” (Carlos, 1965).

8. "De que vale o céu azul e o sol sempre a brilhar/ Se você não vem e eu estou a lhe esperar [...]/ De que vale a minha boa vida de playboy/Se entro no meu carro e a solidão me dói/ Não suporto mais você longe de mim/ Quero até morrer do que viver assim/ Só quero que você me aqueça nesse inverno/ E que tudo mais vá pro inferno" (Carlos, 1965). 
de mais de 10 mil pessoas, mas também cortejava a simpatia das elites em eventos exclusivos no Country Club.

Para fazer valer a tão propalada simplicidade que a imprensa lhe apregoava, realizou shows beneficentes e lançou a campanha de arrecadação de agasalhos Quero que você me aqueça nesse inverno. No intervalo de seu programa, pedia aos "papais e mamães" que não esquecessem de vacinar seus filhos contra a poliomielite. Respondia as cartas do público em seu programa diário na Rádio Jovem Pan; também por escrito, na seção "Roberto Carlos Responde”, da revista Contigo. A filantropia e o diálogo através de cartas eram estratégias saídas, mais uma vez, do rádio: objetivavam a ligação orgânica do ídolo com a audiência (Calabre, 2002). Uma dessas cartas, no entanto, revela bem a natureza do fenômeno Roberto Carlos.

Só hoje separei aqui estes pedidos: de uma menina de seis anos que quer me fazer sócio de sua butique. Outra, daqui de São Paulo, que quer que eu seja padrinho do último filho e que eu consiga o enxoval. De Salvador, o pedido de ajuda para um terreno de Cr\$ 600 mil para uma senhora poder sustentar seus filhos. Um piano para uma casa beneficente da Lapa, no Paraná. Um outro auxílio para uma senhora de Aparecida (sP), que tem quatro filhos e quer abrigá-los num "ranchinho". Uma viúva de Acesita quer financiamento para arrumar o enxoval da filha que vai casar em maio [...]. NCr\$ 500,00 é o que me pede um homem de São Sebastião do Umbuzeiro, para que ele possa continuar nos estudos. Outro jovem de Santo Ângelo, em condições parecidas, me pede NCr\$1.400,00. Do Rio de Janeiro, um motorista que não tem sido muito bem-sucedido me pede que lhe envie... um caminhão. Há ainda um pedido de um barco de pesca para o avô de uma criaturinha muito preocupada com o fracasso do avô, que é pescador. E ainda um sr. Faria de Azevedo que deve ser do Rio pois pede licença para tentar um serviço na casa de minha mãe. Depois de me contar todas as suas misérias, ele me diz que seu sonho é conhecer a Europa e me pede pelo amor de Deus para eu não deixar de atendê-lo. Basta que eu adiante NCr\$ 4.376.00. Voltemos ao caso de Terezinha, que queria uma perua Kombi. Entendeu agora por que eu não posso mandar a sua condução? Espero contar com a compreensão de todas as pessoas que me escrevem nesse sentido. Pessoas que sonham com dádivas impossíveis (Carlos, 1967a, p. 19).

A natureza díspar dos pedidos é reveladora. Estampando sua marca em músicas, discos, livros, concertos, programas de TV, reportagens, campanhas filantrópicas, anúncios de utilidade pública, além de botas, calças e acessórios, Roberto criava uma relação ao mesmo tempo de intimidade e distância com a sua audiência. Ele encarnava desde o vizinho ou familiar mais ou menos abastado com quem se convive algo frequentemente - e que, porventura, poderia socorrer em momento de necessidade -, até a deidade a que se dirigem pedidos impossíveis. 
Quando um padre chegasse a adaptar as canções de Roberto para atrair jovens fiéis, ficava claro o processo de idolatria que cercava o cantor, já afirmado como modelo de comportamento e estilo de vida. Os títulos de cidadão carioca e paulistano confirmavam seu reconhecimento pelo poder instituído. Enquanto isso, ele se tornava o centro de análises de intelectuais articulados em veículos de nicho - é o caso do debate organizado pela Revista Civilização Brasileira, que teve a participação de Nara Leão e Caetano Veloso (Barbosa, 1966) - e também na mídia massiva - é o caso das intervenções de Marialice Forachi na Revista Manchete, analisando o ídolo Roberto Carlos (Foracchi, 1966), e também noJornal do Brasil, em que se propunha a dissecar os significados do carrão para os artistas da música jovem (Foracchi, 1967).

Antes de deixar o programa Jovem Guarda, o cantor protagonizou o filme Roberto Carlos em ritmo de aventura, um precursor do segmento audiovisual jovem que se consolidaria no cinema e na teledramaturgia brasileiras dos anos 1970 (Ortiz Ramos, 1995). Inspirado nos filmes dos Beatles, conta a história de bandidos que tentam substituir Roberto por um robô. Nessa caçada em alta velocidade, o astro aparece a bordo de carro, barco, avião, helicóptero, tanque e até foguete espacial. Uma sequência merece ênfase:

Roberto Carlos canta “Quando” na cobertura de um prédio rodeado de moças, vestindo uma capa preta, num cenário que reproduz uma espécie de sala de visitas ao ar livre. A decupagem e montagem articulam imagens "picadas", mostrando o cantor e as jovens posando como modelos para fotos de moda. No final há um travelling de um beijo de Roberto Carlos com uma das atrizes, num claro estilo publicitário (Idem, p. 234).

Segundo Ortiz Ramos, sequências como essa aproximavam o filme de Roberto de uma estética que, futuramente, seria identificada com a lógica publicitária dos videoclipes. Entretanto, como já sublinhamos, o produto "vendido" aqui não é somente a música, mas um estilo de vida jovem, sintonizado com os valores de hedonismo e consumo. A dimensão industrial não anula, porém, o caráter de unicidade do ídolo Roberto Carlos, um produto singular em seu filão.

Chefe da Quadrilha: Roberto, nós precisamos executar esse plano. Você nunca mais vai precisar trabalhar. Ele vai fazer suas músicas melhor do que você. É um potente cérebro eletrônico trabalhando pra você. [...] Vamos ganhar milhões de dólares.

Roberto Carlos: Essa máquina esqueceu de te dizer uma coisa: que eu gosto de fazer música (Roberto Carlos em ritmo de aventura, 1968). 
As cenas em que sobrevoa o Rio de Janeiro, circundando o Cristo Redentor, ou as tomadas espaciais, acima do planeta Terra, registram a natureza singular de uma celebridade situada em um patamar inatingível e quase extraterreno, tudo reforçado pela canção de abertura do filme, "Eu sou terrível", a qual tinha o condão de desacreditar seus então concorrentes e imitadores. Ao transitar entre a juventude e a massa, entre o rádio e a TV, com muita destreza, Roberto era, enfim, inimitável - título, aliás, de outra de suas canções, lançada no período.

\section{Considerações finais}

Embora Roberto Carlos tenha sido o maior vendedor de discos da década de 1960, sua trajetória representa somente um ângulo de apreensão das enormes mudanças operadas na música popular nessa época. Dentre seus contemporâneos, podemos citar Caetano Veloso e Elis Regina, por exemplo, que também experimentaram as mesmas mudanças, ainda que de forma bastante distinta. O primeiro chegou a frequentar os auditórios da Rádio Nacional ainda nos anos 1950, foi tocado pela bossa nova na virada dessa década e defendeu que o novo estilo estabelecia um passo à frente na linha evolutiva da música popular brasileira; pouco tempo depois, tornava-se um dos cabeças de outro grande movimento, o Tropicalismo. Elis, por sua vez, começou a sua carreira em programas de calouros mirins cantando boleros e sambas-canção, profissionalizou-se no circuito universitário da МРВ е chegou ao estrelato nos Festivais da Canção. Em seus percursos, ambos tiveram de aprender, assim como Roberto, a lidar com o novo meio de comunicação: a televisão.

Nesse sentido, o estudo das trajetórias nos ajuda a lidar ao mesmo tempo com mudanças estruturais, não sem respeitar a singularidade individual, a fim de melhor vislumbrar as formas como cada sujeito traça seus caminhos em meio a constrangimentos compartilhados com seus pares e além do seu controle. Roberto Carlos serve como um caso-teste, portanto, passível de comparação face a tantos outros artistas, se quisermos compreender, afinal, as profundas modificações operadas na música popular ao longo dos anos 1960. 


\section{Referências Bibliográficas}

Araújo, Paulo Cesar. (2006), Roberto Carlos em detalhes. Rio de Janeiro, Planeta.

Bourdieu, Pierre. (1996), “A ilusão biográfica”. In: Amado, Janaina \& Ferreira, Marieta de Moraes (orgs.). Uso e abusos da história oral. Rio de Janeiro, Editora da Fundação Getúlio Vargas, pp. 183-191.

Calabre, Lia. (2002), No tempo do rádio: radiodifusão e cotidiano no Brasil. 1923-1960. Rio de Janeiro, tese de doutorado, Instituto de História da Universidade Federal Fluminense.

Castro Gomes, Angela de \& Hansen, Patricia Santos. (2016), Intelectuais mediadores: práticas culturais e politica. Rio de Janeiro, Civilização Brasileira.

Figueiredo, Ana Cristina. (1998), Liberdade é uma calça velha, azul e desbotada: publicidade, cultura de consumo e comportamento político no Brasil, 1954-1964. São Paulo, Hucitec.

Garson, Marcelo. (2017), "Imprensa de nicho e música jovem no Brasil: 'O Mundo é do Brotos' e Revista do Rock (1960-1965)”. Revista Antiteses, 10: 185-210.

Janssen, Susanne \& Verboord, Marc. (2015), “Cultural mediators and gatekeepers". In: WRIGHT, James D. International Encyclopedia of the social \& behavioral sciences. 2 ed. Oxford, Elsevier, vol 5, pp. 440-446.

Kuschnir, Karina. (2000), O cotidiano da politica. Rio de Janeiro, Zahar, 2000.

Marx, Karl. (1983), O capital. São Paulo, Abril Cultural, vol. I, tomo 1.

McCann, Brian. (2006), Hello, hello Brazil: popular music in the making of modern Brazil. Durham, Duke University Press.

McDonell, Andrea Marie. (2012), Just like us: celebrity gossip magazines in American popular culture. Michigan, tese de doutorado em Comunicação, Universidade de Michigan. Disponível em http://deepblue.lib.umich.edu/handle/2027.42/91613, consultado em 10/1/2020.

Monteiro, Denilson. (2008), Dez! Nota dez! Eu sou Carlos Imperial. São Paulo, Matrix.

Montoya, Nathalie. (2008), "Médiation et médiateurs culturels: quelques problèmes de définition dans la construction d'une activité professionnelle”. Lien Social et Politiques, 60: 25-35.

Ortiz Ramos, José Mário. (1995), Televisão, publicidade e cultura de massas. Petrópolis, Vozes.

Pequignot, Bruno. (2007), “Sociologie et mediation culturelle”. L'Observatoire, 32: 3-7.

SÁ, Simone. (2002), Baiana internacional: as mediaçôes culturais de Carmen Miranda. Rio de Janeiro, MIs Editorial, 2002.

SaCramento, Igor. (2012), Nos Tempos de Dias Gomes: a trajetória de um intelectual comunista nas tramas comunicacionais. Rio de Janeiro, tese de doutorado em Comunicação, Universidade Federal do Rio de Janeiro.

Velho, Gilberto \& Kuschnir, Karina. (2001), Mediação, cultura e política. Rio de Janeiro, Aeroplano.

Vianna, Leticia. (1999), Bezerra da Silva, produto do morro: trajetória e obra de um sambista que não é santo. Rio de Janeiro, Jorge Zahar. 
Williams, Raymond. (1979), Marxismo e literatura. Rio de Janeiro, Zahar.

\section{Artigos de periódicos}

Barbosa, A. I. (coord.). (maio 1966), "Que caminho seguir na música popular brasileira”, Revista Civilização Brasileira, "Debate", 7: 375-385.

Carlos, Roberto. (1967a), "Roberto Carlos responde”, Contigo, p. 19.

ForacCHI, Marialice. (16 abr. 1966), “O ídolo Roberto Carlos”, Manchete, pp. 10-14.

FORACCHI, Marialice. (15 jan. 1967), "O carrão e seus significados ocultos”, Jornal do Brasil, p. 8.

Imperial, Carlos. (22 dez. 1962), “O mundo é dos brotos", Revista do Rádio, p. 29.

Oliveira, José Carlos de. (19 mar. 1966), “Roberto Carlos: a canção dentro do pão”, Manchete, pp. 82-85.

Silva, Alberto. (26 jun. 1958), “Juventude Transviada ataca de noite”, O Cruzeiro, pp. 30-34.

SoAres, Odacir. (22 jan. 1966), "Roberto Carlos: um fenômeno entre os fenômenos". Manchete, pp. 28-31.

“Cauby cercado de brotos por todos os lados”. (12 jan. 1961), Revista do Rádio, p. 15.

"Como Vive o novo ídolo das fẫs: Roberto Carlos". (11 abr. 1964), Revista do Rádio, p. 14.

"Mexericos da Candinha”. (7 out. 1961), Revista do Rádio, p. 15.

"Paixốes de Roberto Carlos: Brotos, música e carros”. (2 jul. 1962), Revista do Rádio, p. 13.

"Periscópio", Diário de Notícias. (8 set. 1966), p. 7.

“Roberto CARlos foge para não ficar nu”. (5 maio 1965), Intervalo, pp. 14-5.

“Toda A vida de Roberto Carlos”. (20 fev. 1965), Revista do Rádio, p. 10.

\section{Discos}

CARlos, Roberto. (1961), Louco por você. Rio de Janeiro, cBs.

Carlos, Roberto. (1963), Splish splash. Rio de Janeiro, cBs.

Carlos, Roberto. (1964), É proibido fumar. Rio de Janeiro, CBS.

Carlos, Roberto. (1965), Roberto Carlos canta para a juventude. Rio de Janeiro, CBS.

Carlos, Roberto. (1965a), Jovem Guarda. Rio de Janeiro, CBs.

Carlos, Roberto. (1966), Roberto Carlos. Rio de Janeiro, CBs.

Carlos, Roberto. (1967b), Roberto Carlos em ritmo de aventura. Rio de Janeiro, CBS.

Carlos, Roberto. (1968), O inimitável. Rio de Janeiro, свs.

\section{Filme}

ROBERTO CARLOS em ritmo de aventura. (1968), Direção de Roberto Farias. 98 min., 35 mm, color, São Paulo, Sonopress; Sony Music Entertainment, DvD. 


\section{Resumo}

Roberto Carlos como mediador cultural: música jovem, TV e rádio

Os anos 1960 experimentaram profundas modificações nas hierarquias de poder da música popular brasileira. Entre as causas para esse fenômeno, duas nos interessam em particular: a perda de centralidade do rádio, que cede terreno à televisão, além da construção de um nicho de música jovem, decorrente do fenômeno da Jovem Guarda. Este artigo tem por objetivo estudar a trajetória de Roberto Carlos nesse período, tomando-o como um mediador cultural, agente de trânsito e intersecção que conformou e adaptou os signos do rádio à televisão e, ao mesmo tempo, conseguiu se afirmar como ídolo das massas, mas também da juventude.

Palavras-chave: Roberto Carlos; Jovem Guarda; Juventude; Rádio; Televisão.

\section{Abstract}

Roberto Carlos as a cultural mediator: youth music, $T V$ and radio

Roberto Carlos as a cultural mediator: youth music, TV and radio

The 1960s experienced deep changes in the hierarchies of power in Brazilian popular music. Two causes for this event deserve special attention: the loss of centrality of radio, which gives way to television, and the construction of a youth music niche, a byproduct of the "Jovem Guarda" phenomenon. This article aims to study Roberto Carlos' trajectory in this period, taking him as a cultural mediator, i. e. an agent who conformed and adapted the signs of radio to television and, at the same time, managed to conquer a position as an idol both of the masses and the youth. Keywords: Roberto Carlos; Jovem Guarda; Youth; Radio; Television.

Texto recebido em 1/4/2020 e aprovado em 9/4/2020.

DOI: $10.11606 / 0103-2070 . t s .2020 .168418$.

Marcelo Garson é professor adjunto do Departamento de Comunicação da Universidade Federal do Paraná, doutor em sociologia pela Universidade de São Paulo. E-mail: marcelogarson@ufpr.br. 